\title{
L-lysiinillä rikastettu kasvivalkuainen kalajauhon korvaajana lihasian rehuseoksessa
}

\author{
Maija-Liisa Salo ja Risto LaAlahti \\ Helsingin yliopiston kotieläintieteen laitos
}

Saapunut 29.11.1972

\section{Vegetable feed mixture supplemented with L-lysine compared with fish meal as protein source for growing pigs}

\author{
Maija-Lirsa Salo and Risto Laalahti \\ Department of Animal Husbandry, University of Helsinki
}

\begin{abstract}
A vegetable feed mixture supplemented with L-lysine was compared with fish meal as a protein supplement in barley diet for growing pigs $(20-88 \mathrm{~kg}$ live weight). The vegetable ration consisted of $60 \%$ soya bean meal, $15 \%$ turnip rape meal and $25 \%$ Torula yeast supplemented with $1 \%$ L-lysine. The protein supplements were each fed to group of 13 barrows and 5 gilts, group I receiving the vegetable feed and group II the fish meal. The two groups received the same daily energy levels, minerals and vitamins, and their diets contained almost the same amounts of crude protein, lysine, methionine + cystine, threonine and tryptophan. The high - low feeding level system was used.

There was a small difference in favour of the fish meal diet for growth rate and feed conversion ratio, and a small difference in favour of the vegetable diet for carcass characteristics, but none of the differences were significant. The main results (group I/group II) were: live weight gain $641 / 663 \mathrm{~g}$ per day, feed conversion ratio $2.71 / 2.63 \mathrm{fu}$ per kg gain, back fat $26.0 / 27.2 \mathrm{~mm}$, side fat $22.8 / 24.5 \mathrm{~mm}$, area of $\mathrm{m}$. long. dorsi 29.9 / $28.9 \mathrm{~cm}^{2}$, lean meat of carcass $45.7 / 45.6 \%$, meat + bone of the most valuable parts of carcass $74.9 / 74.3 \%$, meat gain of the most valuable parts of carcass $91 / 91 \mathrm{~g}$ per dat.

The profit was almost the same in the two groups.

A transition period was found to be necessary for group II. However, after the pigs had become accustomed to the diet, the rather high turnip rape content $(39-30 \mathrm{~g} /$ day $)$ did not appear to have any harmful effects.
\end{abstract}

Aikasemmin pidettiin sääntönä, että sikojen ja kanojen rehuun täytyy sisältyä animaalista valkuaista ennen kuin saadaan hyvä kasvu- ja rehun hyväksikäyttötulos. Nykyisen tietämyksen mukaan eläinvalkuainen sinänsä ei ole välttämätön tekijä, oleellista on että eläin saa rehusta tarpeeksi raakavalkuaista ja välttämättömiä aminohappoja. Koska nykyisin sikojen amino- 
happotarve tunnetaan (RERAt ja Lougnon 1968, Lewis ja HARDY 1970), rehujen aminohappopitoisuudet voidaan määrittää tai katsoa rehutaulukoista ja myös eri rehujen aminohappojen resorboitumisesta sioilla on olemassa tutkimuksia (Poppe ja Meier 1970, Eggum 1971, Nielsen 1971), on mahdollista laskea käytettävissä olevista rehuista sopiva seos. Kasvirehujen aminohappokoostumus ei vastaa eläinten tarvetta yhtä hyvin kuin useimpien eläinperäisten rehujen, mutta tätä seikkaa voidaan korjata lisäämällä seokseen synteettisiä aminohappoja, jolloin vältytään raakavalkuaisen turhan runsaalta käytöltä. Pelkästään kasviperäisellä rehulla onkin saatu hyviä tuloksia niin sioilla (Thier et al. 1969, Madsen et al. 1970, Partanen 1970, Jucker 1971, BARBer et al. 1971) kuin kanoillakin (COOPER et al. 1960, Aitken et al. 1967, Vogt 1968, Lehtonen ja PaAvilainen 1971).

Tässä tutkimuksessa selviteltiin mahdollisuutta korvata lihassikojen ruokinnassa kalajauho kasvirehuseoksella, johon oli lisätty L-lysiiniä. Kumpikin ryhmä sai saman rehuyksikkömäärän päivässä ja rehujen raakavalkuais- sekä tärkeimpien aminohappojen pitoisuudet olivat lähes samat. Vertailussa huomioitiin kasvu, rehun hyväksikäyttö, ruhon laatu ja taloudellinen tulos.

Kokeen taustana oli varautuminen siihen, että kalajauhon saanti saattaa tyrehtyä tai ainakin sen hinta merkittävästi nousta. Kokeen suoritusaikaan kalajauho oli taloudellisesti edullisin sikojen valkuaisrehu. Nyt kun runsas vuosi kokeen suorittamisesta on kulunut on tilanne kalajauhon kohdalla paljolti huonontunut: Kilohinta on noussut 90 pennistä 1.85 markkaan ja on yhä nousussa ja maahantuonti tälläkin hinnalla näyttää olevan vaikeutumassa.

\section{Kokeen järjestely}

E 1 ä i m e t. Koe suoritettiin Valtion sikakoeasemalla Hyvinkäällä. Koeeläimet olivat sikakoeaseman omasta emakkosikalasta yorkshire ja maatiaisrodun risteytyseläimiä. Neljää lukuunottamatta ne olivat kahden karjun jälkeläisiä ja karjut olivat lisäksi saman karjun poikia. Porsaat jaettiin mahdollisimman identtisiksi ryhmiksi. Kummassakin ryhmässä oli 18 eläintä, niistä 13 leikkoa ja 5 imisää. Siat olivat kahden eläimen karsinoissa, 4 leikkoparia, 1 imisäpari ja 4 sekaparia kummassakin ryhmässä. Porsaiden alkupainot olivat keskimäärin $19.4 \mathrm{~kg} / 19.6 \mathrm{~kg}$. Varsinaista koeaikaa oli $20-88$ elopainokilon välinen aika.

Re h u t j a ruokint a. Perusrehuna oli ohra, valkuaisrehuna vertailuryhmällä hyvälaatuinen norjalainen sillijauho ja koeryhmällä seos, joka sisälsi $60 \%$ soijarouhetta, $15 \%$ rypsirouhetta ja $25 \%$ Torula hiivaa. Seokseen lisättiin $1 \%$ sen painosta L-lysiiniä. Kivennäis- ja vitamiiniseosta annettiin sellaiset määrät, että ne tärkeimpien kivennäisten, hivenaineiden ja vitamiinien osalta vastasivat normien mukaista tarvetta. Rehujen analyysitulokset ja niiden pohjalla tehty ry- ja srv-laskelma näkyy taulukossa 1 .

Ruokinnassa noudatettiin Valtion sikakoeasemalla kehitettyä runsas-niukka normitusta (PARTANEN 1970). Päivittäin käytetyt rehumäärät käyvät ilmi taulukosta 2 , ry-määrät ja rehun raakavalkuais- ja tärkeimpien välttämättö- 
Taulukko 1. Analyysitulokset rehuista ja niiden perusteella laskettu energia- ja sulavaraakavalkuaisarvo.

Table 1. Composition, energy and digestible crude protein values of feeds.

\begin{tabular}{|c|c|c|c|c|c|c|c|c|c|c|}
\hline & $\begin{array}{l}\text { है } \\
\text { है } \\
1 \\
5 \\
5\end{array}$ & 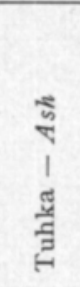 & 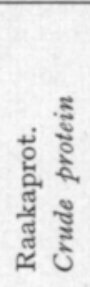 & 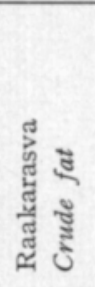 & 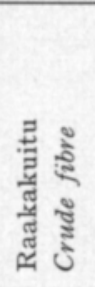 & 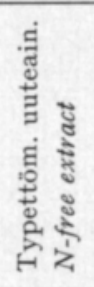 & 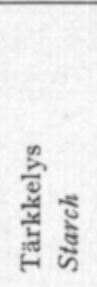 & 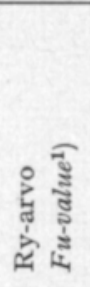 & 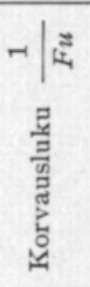 & 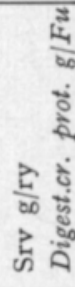 \\
\hline Ohra $\ldots \ldots \ldots \ldots \ldots \ldots \ldots \ldots \ldots$ & 11.8 & 2.5 & 12.3 & 2.3 & 4.6 & 66.5 & 49.9 & 0.9 & 1.1 & 102 \\
\hline Barley & & & & & & & & & & \\
\hline $\begin{array}{l}\text { Kalajauho } \\
\text { Fish meal }\end{array}$ & 6.6 & 11.4 & 72.0 & 8.1 & - & 1.9 & - & 1.1 & 0.9 & 595 \\
\hline $\begin{array}{l}\text { Kasvisrehuseos .............. } \\
\text { Vegetable mixture }\end{array}$ & 10.6 & 6.0 & 47.4 & 2.3 & 6.8 & 26.9 & - & 1.0 & 1.0 & 420 \\
\hline
\end{tabular}

1 feed unit $=0.7$ starch units

Taulukko 2. Rehumäärät eri painoluokissa (g ilmakuivaa rehua/sika/pv).

Table 2. Rates of feeding (g. air-dry feed/pig/day).

\begin{tabular}{|c|c|c|c|c|c|c|}
\hline \multirow[b]{2}{*}{$\begin{array}{c}\text { Sian paino } \mathrm{kg} \\
W t \text {. of pig } \mathrm{kg}\end{array}$} & \multicolumn{3}{|c|}{ Koeryhmä, Group I } & \multicolumn{3}{|c|}{ Vertailuryhmä, Group II } \\
\hline & $\begin{array}{l}\text { Ohra } \\
\text { Barley }\end{array}$ & $\begin{array}{l}\text { Kasvis- } \\
\text { seos } \\
\text { Vegetable } \\
\text { mixture }\end{array}$ & $\begin{array}{l}\text { Kivennäis- } \\
\text { seos }^{1} \text { ) } \\
\text { Mineral } \\
\text { supplement } \\
\text { 1) }\end{array}$ & $\begin{array}{l}\text { Ohra } \\
\text { Barley }\end{array}$ & $\begin{array}{l}\text { Kalajauho } \\
\text { Fish meal }\end{array}$ & $\begin{array}{c}\text { Kivennäisseos }^{1} \text { ) } \\
\left.\text { Mineral }^{\text {supplement }}{ }^{\mathbf{1}}\right)\end{array}$ \\
\hline $20 \ldots \ldots \ldots \ldots$ & 960 & 260 & 40 & 1050 & 160 & 40 \\
\hline 25 .................. & 1060 & , & , & 1150 & , & , \\
\hline $30 \quad \ldots \ldots \ldots \ldots \ldots \ldots$ & 1260 & . & , & 1350 & , & , \\
\hline 35 ................. & 1410 & , & , & 1500 & , & , \\
\hline 40 .......................... & 1610 & 250 & 50 & 1700 & 150 & 50 \\
\hline $45 \ldots \ldots \ldots \ldots \ldots$ & 1810 & , & , & 1900 & 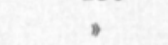 & , \\
\hline 50 .................. & 2010 & , & , & 2100 & , & , \\
\hline 55 ..................... & 2210 & , & , & 2300 & , & , \\
\hline $60-90 \ldots \ldots \ldots \ldots \ldots \ldots$ & 2410 & 200 & , & 2490 & 115 & 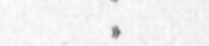 \\
\hline
\end{tabular}

1) Lisäksi sikojen vitamiiniseosta $10 \mathrm{~g} / \mathrm{pv}$.

1) In addition vitamin supplement $10 \mathrm{~g} /$ day

mien aminohappojen pitoisuudet taulukosta 3. Päivittäiset rehumäärät oli laskettu sellaisiksi, että kumpikin ryhmä sai saman ry-määrän/pv ja lisäksi kummankin rehuyhdistelmän raakavalkuais-, lysiini-, metioniini + kystiini-, treoniini- ja tryptofaanipitoisuus oli likimain sama ja vastasi sikojen tarvetta (LEwis ja Hardy 1970). Aminohappopitoisuudet laskettiin NJF:n rehutaulukon (1969) keskiarvojen mukaan, koska koerehuista tehty aminohappomääritys vaikutti epäluotettavalta. 
Taulukko 3. Energian saanti ja rehuyhdistelmien raakavalkuaisen ja tärkeimpien aminohappojen pitoisuudet (\% ilmakuivasta rehusta).

Table 3. Intake of energy/pig/day, crude protein and main amino acid contents of rations ( $\%$ air-dry feed).

\begin{tabular}{|c|c|c|c|c|c|c|c|c|c|c|c|}
\hline \multirow[b]{2}{*}{ 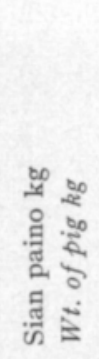 } & \multirow[b]{2}{*}{ 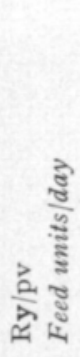 } & \multicolumn{2}{|c|}{ Koerehu } & \multicolumn{3}{|c|}{ Ration for group I } & \multicolumn{2}{|c|}{ Vertailurehu } & \multicolumn{3}{|c|}{ Ration for group II } \\
\hline & & 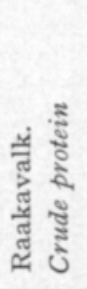 & 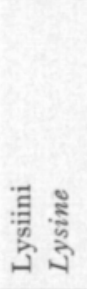 & 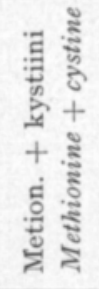 & 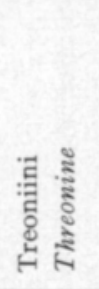 & 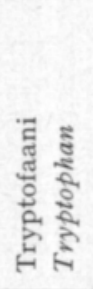 & 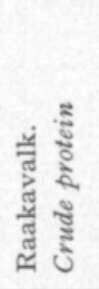 & 悬芯 & 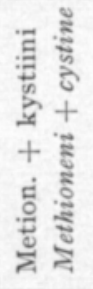 & 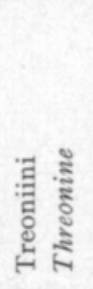 & 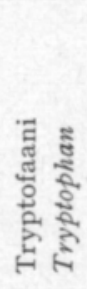 \\
\hline 20 & 1.12 & 19.8 & 1.08 & 0.69 & 0 . & 0.20 & 20.2 & 1.12 & 0.83 & 0.75 & 0.21 \\
\hline 25 & 1.2 & & & & & & & & & & \\
\hline 30 & 1.39 & 18.3 & 0.95 & 0.65 & 0.6 & 0.18 & 18.6 & 0.98 & 0.77 & 0.68 & 0.19 \\
\hline 35 & 1. & & & & & & & & & & \\
\hline 40 & 1.70 & 17.0 & 0.83 & 0.62 & 0.61 & 0.17 & 17.1 & 0.85 & 0.70 & 0.63 & 0.18 \\
\hline 43 & 1.8 & & & & & & & & & & \\
\hline 50 & 2.06 & 16.2 & 0.75 & 0.60 & 0.58 & 0.16 & 16.3 & 0.77 & 0.67 & 0.59 & 0.16 \\
\hline 55 & 2.24 & & & & & & & & & & \\
\hline-90 & 2.37 & 15.0 & 0.64 & 0.57 & 0.51 & 0.15 & 14.9 & 0.65 & 0.61 & 0.53 & 0.16 \\
\hline
\end{tabular}

Päiväannokset laskettiin olettaen, että ohran korvausluku on tavanomainen 1.0. Silloin $20 \mathrm{~kg}$ painoinen sika olisi saanut $1.20 \mathrm{ry} / \mathrm{pv}$ ja annoksen suuruusolisi siitä asteittain noussut $2.60 \mathrm{ry} / \mathrm{pv}$ maksimimäärään $60 \mathrm{~kg}$ painoon päästäessä. Analyysien perusteella myöhemmin tehty laskelma osoitti kuitenkin, että ohra oli normaalia heikompaa, sen ry-arvo oli vain 0.9 ja sen vuoksi sikojen energiansaanti jäi lähes $10 \%$ suunniteltua alhaisemmaksi (Taulukko 3). Ohra oli vuoden 1970 satoa ja sen laadun heikkous kävi sittemmin ilmi myös NJF:n ohratutkimuksesta (SALo 1972). Syynä oli ilmeisesti vuodelle ominainen runsas jälkiversonta.

Siat ruokittiin kaksi kertaa päivässä. Ruoka annettiin puuromaisena, vettä ja jauhoa suhteessa 1: 1 . Vettä sioilla oli vapaasti saatavana.

$\mathrm{K}$ o k e e $\mathrm{n} \mathrm{k} \mathrm{u} \mathrm{l} \mathrm{k} \mathrm{u.} \mathrm{Varsinaista} \mathrm{koeaikaa} \mathrm{oli} \mathrm{20-88} \mathrm{elopainokilon} \mathrm{välinen}$ aika. Koe jouduttiin aloittamaan liian suurilla porsailla ja sen vuoksi melkein välittömästi rehun vaihdon jälkeen. Vaihdon haittavaikutuksia lievennettiin antamalla porsaille ensimmäisinä päivinä normeja pienempi annos. Vertailuryhmä lähti käyntiin varsin kitkattomasti, mutta koeryhmä olisi vaatinut vähin erin tapahtuvan rehujen vaihdon. $260 \mathrm{~g}$ :n päiväannos valkuaisseosta ilmeisesti sen sisältämä 39 g rypsijauhoa - aiheutti 20-kiloisille porsaille tottumisvaikeuksia. Se ilmeni syömättömyytenä ja joillakin myös ripulina. Tottuminen rehuun kesti noin viikon. Tämä alkuvaikeus näkyy kasvukäyrässä, koeryhmä jäi sen vuoksi heti lähdössä vertailuryhmästä jälkeen.

Alkuhankaluuksia lukuunottamatta koe sujui hyvin. Siat olivat terveitä, joitakin loppuajan jalkaheikkoustapauksia lukuunottamatta. Jalkaviatkin olivat kuitenkin niin lieviä, että ne tuskin vaikuttivat kasvutuloksiin. Jalkaheik- 
koutta ilmeni tietyn karjun jälkeläisissä, yhțä hyvin molemmissa ryhmissä ja se ilmeisesti johtui perinnöllisistä taipumuksista eikä rehusta.

Ruhon a rvost elu. Siat lähetettiin teuraaksi, kun kahden peräkkäisen päivän painon keskiarvo oli vähintäin $88 \mathrm{~kg}$. Teurastus ja ruhojen arvostelu tapahtui Karjakunnan teurastamossa Helsingissä. Ruhot arvosteltiin Valtion sikakoeaseman sikakantakokeissa käyttämien normien mukaan, esim. selkäsilavan mitta on viidestä kohdasta saadun luvun keskiarvo. Ruhon paloittelulla selvitettiin $\mathrm{mm}$. ruhon arvokkaiden osien liha-luuprosentti ja ruhon lihakkuusprosentti.

\section{Tulokset}

Sikojen kasvukäyrät nähdään kuvasta 1 ja koetulokset kokonaisuudessaan taulukosta 4 .

Kuvasta käy ilmi jo esiintullut seikka, että koeryhmä jäi jälkeen heti kokeen alussa, mikä ero sitten hiljalleen suureni erikoisesti kokeen loppuviikkoina. Keskimääräinen päiväkasvu ja rehun hyötysuhde jäi sen vuoksi koeryhmällä vähän vertailuryhmän arvoja heikommaksi, mutta erot eivät olleet tilastollisesti merkitseviä. Rehun hyötysuhde oli myös heikommaksi jääneellä koeryhmällä erittäin hyvä.

Teuraslaadussa - sekä silavamitoissa että lihakkuusarvoissa - ilmeni pieniä eroja koeryhmän hyväki, mutta tilastollista merkitsevyyttä niilläkään ei ollut. Taulukossa 4 esitettyjen numerotietojen lisäksi määritettiin mm. kylkikappaleen lihakkuus ja lihan väri, mutta eroja ryhmien välillä ei todettu. Silavamitat olivat suhteellisen ohuet ja koska ruhojen laatuluokitus suoritetaan silavamittojen mukaan pääsi suuri osa ruhoista (koeryhmästä 13, vertailuryhmästä 9) laatuluokkaan $1+$, mikä silloin oli korkein.

Kokeesta tehtiin myös taloudellinen laskelma. Siitä kävi ilmi, että tässäkään kohden ei ryhmien välillä ollut oleellista eroa. Katetuottoero vertailuryhmän hyväksi oli vajaa $2 \%$. Koeryhmän ruhoista saatu vähän korkeampi hinta nimittäin kompensoi ryhmän vähän korkeampaa rehukustannusta. Viimeksimainittua nosti sekä lysiini että rehuhiiva, joka valkuaissisältöönsä nähden oli huomattavasti kalliimpaa kuin kalajauho, joka tuolloin maksoi vain $90 \mathrm{p} / \mathrm{kg}$. Taloudellinen tulos oli itse asiassa normaalia parempi, koska rehun hyvän hyötysuhteen aiheuttama rehun säästö ja ruhojen korkea laatu painoi vaa'assa enemmän kuin suuren energiarajoituksen aiheuttama kasvatusajan pidentyminen. Tulosta paransi myös se seikka, että kuolemantapauksia ei sattunut eikä liioin hoitoa vaativaa sairautta. Huomattakoon että koerehua suunniteltaessa rehun hinta jäi vähälle huomiolle; täysipainoisen kasvivalkuaisrehun voisi suunnitella kilohinnaltaan edullisemmaksikin.

\section{Tulosten tarkastelu}

Tulosten vertailua aikaisempiin vaikeuttaa eri maiden välillä vallitseva sekä energianormien että energiamittojen kirjavuus. On ad. libitum ruokintaa ja 


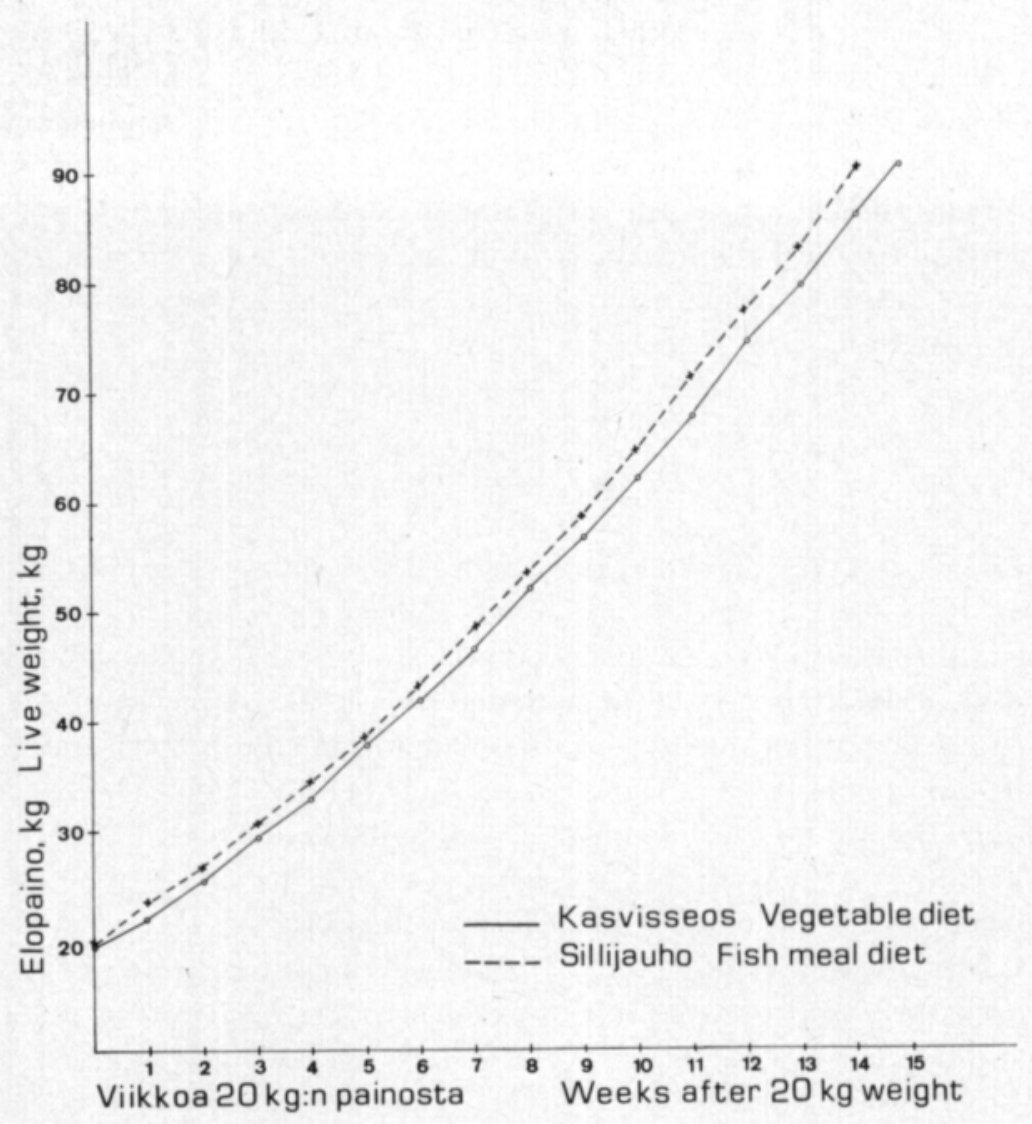

Kuva 1. Sikojen kasvukäyrät.

Fig. 1. Growth curves for pigs.

erilaisia rajoitusmalleja ja toisaalta sulavaa, muuntokelpoista ja nettoenergiaa sekä paino- että kalorimittoina.

Yleispiirteenä kokeen tuloksista voidaan sanoa, että koerehu oli vähän heikompaa kuin kalajauho, joskaan ryhmien välillä ei missään kohden todettu tilastollisesti merkitseviä eroja. Kasvueroa syntyi ryhmien välille heti kokeen alussa, jolloin porsaat oudoksuivat kasviseosta, ilmeisesti sen rypsijauhoosuutta, joka kokeen ensimmäisenä viikkona oli $3.2 \%$ rehuyhdistelmästä $(60$ $\mathrm{kg}$ painosta lähtien enää $1.1 \%$ ). Rypsijauhosta ei liene tutkimuksia, mutta rapsijauhosta saadut tulokset pätevät myös rypsijauhoon. SABEN et al. (1971) osoittivat, että lihasika sulattaa rapsijauhoa melkoisesti huonommin kuin soijajauhoa (sulavuudet 75.9 ja $89.2 \%$ ). Hansen ja Clausen (1969) totesivat ruokintakokeissa, että $175 \mathrm{~g}$ ja $350 \mathrm{~g}$ :n päiväannos uutettua rapsijauhoa alensi huomattavasti rehun maittavuutta ja sitä tietä kasvutulosta. Kilpirauhasen paino nousi rapsiryhmillä hyvin selvästi. CLAPS et al. (1972) ilmoittavat vuorostaan, että 30-90 kilon painovälillä 3 ja $6 \%$ rapsijauhoa rehuyhdistelmästä antoi saman kasvutuloksen kuin kontrollirehu, jossa rapsin tilalla oli maa- 


\begin{tabular}{|c|c|c|}
\hline Eläinten määrä - Number of pigs .... & 18 & 18 \\
\hline Elopaino alussa, $\mathrm{kg}-$ Live wt. at the beginning, $\mathrm{kg} . \ldots \ldots \ldots \ldots \ldots . . . . .$. & 19.4 & 19.6 \\
\hline Korjattu elopaino lopussa, $\mathrm{kg}-$ Corrected live wt. at the end, $\mathrm{kg}$. & 87.8 & 87.3 \\
\hline Teuraspaino, kg - Slaughter weight, $k g$.......................... & 65.9 & 65.5 \\
\hline 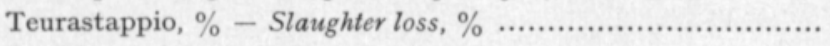 & 26.7 & 27.3 \\
\hline Ruokintapäiviä - Feeding days ................................ & 107 & 102 \\
\hline Elopainon kasvu, g/pv - Live wt. gain, g/day ...................... & 641 & 663 \\
\hline Rehunkulutus, ry/elop. kasvu $\mathrm{kg}-$ Feed intake, fu/kg live wt.gain & 2.71 & 2.63 \\
\hline Rehunkulutus, ry/eläin/pv - Feed intake, fu/pig/day ............ & 1.80 & 1.76 \\
\hline Selkäsilava, mm - Back fat, mm ................................ & 26.0 & 27.2 \\
\hline Kylkisilava, mm - Side fat, $m m$............... & 22.8 & 24.5 \\
\hline Kyljyslihas, $\mathrm{cm}^{2}-M$. long. dorsi, $\mathrm{cm}^{2}$......... & 29.9 & 28.9 \\
\hline 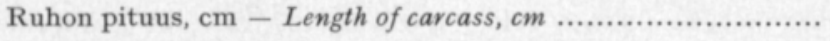 & 98.0 & 97.5 \\
\hline 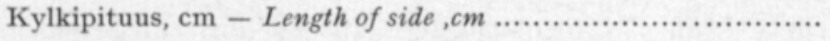 & 77.8 & 77.2 \\
\hline Lihaa ruhosta, $\%$ - Lean meat, $\%$ of carcass ..................... & 45.7 & 45.6 \\
\hline 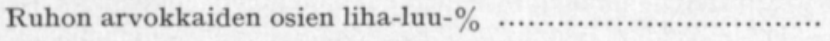 & 74.9 & 74.3 \\
\hline \multicolumn{3}{|l|}{ Meat + bone of the most valuable parts of carcass, $\%$} \\
\hline 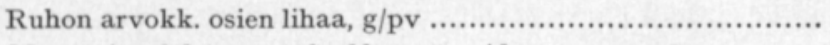 & 91 & 91 \\
\hline \multicolumn{3}{|l|}{ Meat gain of the most valuable parts, g/day } \\
\hline Luokitus - Classification: $1+\ldots \ldots \ldots$ & 13 & 9 \\
\hline 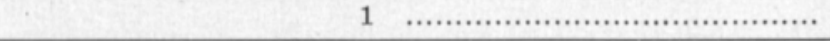 & 6 & 9 \\
\hline
\end{tabular}

1) Mitkään erot ryhmien välillä eivät ole merkitseviä.

1) None of the differences between the groups are significant

pähkinä- tai pellavansiemenjauhoa. 9 ja $12 \%$ rapsijauhoa sen sijaan sai aikaan merkitsevästi heikomman tuloksen.

Kirjoittajan suorittamassa kokeessa rypsijauhon maksimimäärä oli $39 \mathrm{~g}$ päivässä ja kokeen alussa tämän ryhmän porsailla ilmeni syömättömyyttä ja joillakin myös ripulia, mitkä voidaan panna rypsijauhon tilille. Viikon parin tottumisvaiheen jälkeen ei mitään näkyvää haittavaikutusta enää pantu merkille. On mahdotonta sanoa, johtuiko koeryhmän kokonaisuudessaan hiukan heikompi kasvu yksinomaan rypsijauhosta, vai oliko se monien tekijäin yhteisvaikutusta. Edellämainittujen Claps et al. tulosten mukaan näin pienen määrän ei pitäisi alentaa kasvua. Ohjeeksi voidaan kuitenkin antaa, että jos valkuaisrehu sisältää näinkin paljon rypsijauhoa, on porsaat totutettava rehuun parin viikon siirtoruokinnalla.

Rehun hyötysuhde osoittautui molemmilla ryhmillä erittäin hyväksi ja samoin ruhon laatu. Kumpaankin vaikutti ilmeisesti sekä huomattava energiarajoitus että rehujen korkea raakavalkuais- ja tärkeimpien aminohappojen pitoisuus ja aminohappojen keskinäinen tasapaino. BLAIR et al. (1969) ja LEWIS ja HARDY'n (1970) mukaan energiarajoitus ja rehun riittävä raakavalkuais- ja lysiinipitoisuus parantavat rehun hyötysuhdetta ja nostavat lihan osuutta ruhossa. 
Jos tarkastellaan sikoja yksilöllisesti eikä vain ryhmien keskiarvolukuina, voidaan todeta että sika-aines oli varsin heterogeenista vaikka käytettävänä olikin koeaseman emakkosikalan porsaat. Esimerkkinä yksilöllisistä eroista mainittakoon, että kahden samasta pahnueesta olevan samaan ryhmään kuuluneen sian pitkän selkälihaksen poikkileikkaukset olivat $40.4 \mathrm{~cm}^{2}$ ja 26.0 $\mathrm{cm}^{2}$. Tämä on omiaan osoittamaan, että jalostusvalintaa tarvitaan ja myös selittämään, miksi ruokintakokeissa tarvitaan suuret ryhmät ennenkuin ruokinnan vaikutus saadaan esille. DAveyn ja Morganin (1969) koe vartavasten jalostetulla silava/lihatyypillä on havainnollinen näyttö tyypin vaikutuksen ruokintakokeen tuloksiin.

Taloudellinen laskelma osoitti, että hyvä ruhon laatu ja rehun hyvä hyötysuhde on kannattavampi tavoite kuin korkea päiväkasvu. Näin siitäkin huolimatta, että hintaero ohutsilavaisen ruhon hyväksi on meillä suhteellisen pieni, koska silavalla on kysyntää markkarateollisuudessa.

Johtopäätöksenä voidaan sanoa, että ilman animaalista valkuaista päästään hyvään tulokseen, kunhan ruokinta suunnitellaan siten, että rehuyhdistelmä aminohappojenkin osalta vastaa sikojen tarvetta. Yksinomaan kasviperäisiä rehuja käytettäessä jää lysiinipitoisuus helposti liian alhaiseksi ja muodostuu rajoittavaksi tekijäksi. Rehujen hinnat määräävät, kannattaako lysiinivajaus täyttää käyttämällä tavallista suurempaa määrää kasvivalkuaisseosta, vaiko lisäämällä vähän synteettistä lysiiniä, jolloin voidaan pysytellä suhteellisen alhaisissa raakavalkuaisnormeissa. Muista aminohapoista tuskin tulee puute meikäläisissä rehuyhdistelmissä, koska niissä on perusrehuna ohra ja kaura, jotka sisältävät kriittisiä aminohappoja huomattavasti enemmän kuin maissi ja vehnä. Tietty valkuaisrehulisäys joka tapauksessa tarvitaan, sillä vilja on aminohappokoostumukseltaan siinä määrin heikkoa, että suhteellisen runsaastikaan raakavalkuaista sisältävät ohralajikkeet eivät - edes muutamalla synteettisellä aminohapolla täydennettynä - riitä lihasian ainoaksi rehuksi silloin kun tavoitteena on hyvä rehunkäyttötulos ja korkean laatuluokan ruhoja.

\section{Yhteenveto}

Lihasikojen ruokinnassa verrattiin kalajauhoa ja seosta, jossa oli $60 \%$ soijajauhoa, $15 \%$ rypsijauhoa, $25 \%$ Torulahiivaa ja lisänä $1 \%$ L-lysiiniä. Perusrehuna oli ohra. Vitamiineja, kivennäis- ja hivenaineita annettiin normien mukaan. Energiamäärät/pv olivat kummallakin ryhmällä samat ja rehun raakavalkuais-, lysiini-, metioniini + kystiini-, treoniini- ja tryptofaanipitoisuudet jokseenkin samat. Ruokinnassa noudatettiin runsas-niukka järjestelmää. Siat olivat kahden eläimen karsinoissa ja kumpaankin ryhmään kuului 18 yorkshire $\mathrm{x}$ maatiainen sikaa, suurin osa leikkoja. Koeaikaa oli $20-88$ elopainokilon välinen aika.

Koeryhmän (I) kasvu- ja rehunkäyttötulos muodostui vähän heikommaksi kuin kalajauhoryhmän (II) ja ruhon laatu vuorostaan vähän paremmaksi. Mitkään erot eivät olleet tilastollisesti merkitseviä. Tärkeimmät numerotiedot ryhmien I ja II välillä olivat: Päiväkasvu 641/663 g, rehun hyötysuhde 
$2.71 / 2.63 \mathrm{ry} / \mathrm{kg}$, selkäsilava $26.0 / 27.2 \mathrm{~mm}$, kylkisilava $22.8 / 24.5 \mathrm{~mm}$, pitkä selkälihas $29.9 / 28.9 \mathrm{~cm}^{2}$, ruhon lihaosuus $45.7 / 45.6 \%$, ruhon tärkeimpien osien a) liha-luuosuus $74.9 / 74.3 \%$, b) lihamäärän kasvu 91/91 g/pv.

Taloudellisessa tuloksessa ryhmien välillä ei ollut mainittavaa eroa.

Kasvirehuseos olisi edellyttänyt parin viikon siirtoruokinnan, sellaista ei ollut ja kasvueroa syntyi heti alussa. Tottumusvaiheen jälkeen ei kasviseoksen melko korkeasta rypsijauhopitoisuudesta ollut haittaa, mikäli ei pientä kasvueroa lasketa yksinomaan rypsin tilille.

Tekijäin kiitokset Raision Tehtaat Oy:lle, joka on lahjoittanut kokeessa käytetyt rehut.

\section{KIRJALLISUUTTA}

Aitken, R. J., Biely, J., Nikolaiczuk, N., Robblee, A. R. \& Slinger, S. J. 1967. Comparison of laying rations with and without animal protein at the Canada Central Random Sample Test. Poultry Sci. 46: 1227.

Barber, R. S., Braude, R., Mitchell, K. G. \& Myres, A. W. 1971. The value of hydrocarbon grown yeast as a source of protein for growing pigs. Brit. J. Nutr. 25: 285-294.

Blair, R., Dent, J. B., English, P. R. \& Raeburn, J. R. 1969. Protein, lysine and feed intake level effects on pig growth. I. Main effects. J. Agric. Sci., Camb. 72: 379-400.

Cooper, D., MArch, B. \& Biely, J. 1960. The performance of laying pullets fed rations differing in cereal component and protein supplement. Poultry Sci. 39: 1395-1400.

Davey, R. J. \& Morgan, D. P. 1969. Protein effect on growth and carcass composition of swine selected for high and low fatness. J. Anim. Sci. 28: 831-836.

Egqum, B. O. 1971. Protein i korn og frø. NJF-kongressen Uppsala 1971. Seksjon II, V og VI: $1-11$.

Glaps, J., Dejneka, F. \& Przysiecka, M. 1972. Rapeseed oilmeal for fattening pigs. Roczniki Nauk Rolniczych 93 B: 7-26. (Ref. Nutr. Abstr. Rev. 42: 1281).

Hansen, V. \& Clausen, HJ. 1969. Rapsskrå til slagterisvin. Landøkonomisk Forsøgslaboratoriums Årbog: 36-56.

JúKeR, H. 1971. Ersatz von Fischmehl durch andere Eiweissfuttermittel in praktischen Schweinemastrationen. Bayer. landw. J. buch 48: 80-92.

Lehtonen, U.-R. \& PAavilainen, M. 1971. Synteettiset aminohapot animaalisen valkuaisen korvaajana kananrehuseoksissa. Siipikarja 1971: 238-239.

LEwIS, D. \& HARDY, B. 1970. The effect of dietary energy and protein on carcass composition in the growing pig. Ritene Conference, Majorca, May 1970, 18 p.

Madsen, A., Eggum, B., Mortensen, H. P. \& Larsen, A. E. 1970. Protein and amino acid supplementation to all-barley diets for pigs with special reference to the amino acid composition of the meat. Kgl. Vet. Landbohøjsk. Årsskr.: 1-11.

Nielsen, A. J. 1971. The digestibility of amino-acids from different balanced feed rations as related to the digestibility of nitrogen in growing pigs. Acta Agric. Scand. 21: 189-192.

NordisK JoRDBRUKSFORSKNING 1969. Fodermiddeltabel. p. 32-33. Gjøvik.

PARTANen, J. 1970 a. Rehuhiivastako kotimainen sikojen valkuaisrehu. Sika 1970, 2: $12-23$.

- 1970 b. Lihasikojen uudet viikottaiset ry-normit. Sika 1970, 4:6-18.

Poppe, S. \& Merer, H. 1971. Zur Bestimmung der Aminosäurenresorption bei Ratte und Schwein. Arch. Tierernähr. 21: 619-633. 
Rerat, A. \& Lougnon, J. 1968. Amino acid requirements of growing pigs. World Rev. Anim. Prod., IV. No. 19-20: 65-74.

Saben, H. S., Bowland, J. P. \& Hardin, R. T. 1971. Digestible and metabolizable energy values for rapeseed meals and for soybean meal fed to growing pigs. Can. J. Anim. Sci. 51: $419-425$.

SALo, M.-L. 1972. Høsttidspunktets indflydelse på byggens fodervaerdi. C. Kolhydrat- och ligninhalt. 395. beretning fra forsørgslaboratoriet, Købehavn: 54-59.

ThIER, E. \& BRUne, H. 1969. Untersuchungen zum Einsatz von L-Lysin-HCl und DL-Methionin in der Schweinemast und zum Aussagewert der ermittelten N-Bilanzen. Z. Tierphys. Tierernähr. Futtermittelk. 24: 209-229.

VoGr, H. 1968. Versuche über den vollständigen Ersatz von Fischmeal durch pflanzliche Eiweissträger. Arch. Geflügelk. 32: 225-341. 